JPE (Jurnal Pendidikan Edutama) Vol. 7 No. 1 Januari 2020

P-ISSN : 2339-2258 (Print) E-ISSN: 2548-821X (Online)

http://ejurnal.ikippgribojonegoro.ac.id/index.php/JPE

\title{
GRAPH THEORY AS A TOOL FOR GROWING MATHEMATICAL CREATIVITY
}

\author{
Puput Suriyah $^{1)}$, S.B Waluya ${ }^{2)}$, $\operatorname{Rochmad}^{3)}$ Wardono $^{4)}$ \\ ${ }^{1}$ IKIP PGRI Bojonegoro \\ email: puput.suriyah@ikippgribojonegoro.ac.id \\ ${ }^{2,3,4}$ Universitas Negeri Semarang \\ 2email: s.b.waluya@mail.unnes.ac.id \\ 3email: rachmad_manden@ mail.unnes.ac.id \\ 4email: wardono@mail.unnes.ac.id
}

\begin{abstract}
Abstrac: The purpose of this research to describe about graph theory is subject can serve as a tool for growing mathematical creativity. Systematic Literature Review (SLR) is used as a method of analyzing a wide range of articles and literature were obtained through searching of data sources. The results of the analysis of various sources elaborated reviews about the open ended questions of graph theory that are used as a disclosure in growing the mathematical creativity of students based on Bahar \& Maker's theory modifications are open ended questions that have characteristics such as fluency and flexibility and have been done in detail/elaboration. Fluency on theory graph can be known when students do task/exercises such as isomorphic graph. Flexibility on theory graph can be known when students do task/exercises, example about spanning trees. In this paper also we showed how can use graph theory to teach standards of NCTM (National Council of Teachers on Mathematics of America) that related with mathematical creativity.
\end{abstract}

Keyword: graph theory, mathematical creativity, fluency, flexibility

\begin{abstract}
Abstrak: Tujuan penelitian ini untuk mendeskripsikan graf teori merupakan salah satu alat untuk menumbuhkan kreativitas matematika. Systematic Literature Review (SLR) digunakan sebagai metode dalam menganalisis sebagai berbagai artikel dan literatur yang diperoleh melalui pencarian sumber data. Hasil analisis dari berbagai sumber tersebut dijabarkan ke dalam ulasan tentang pertanyaaan terbuka dari teori graf yang digunakan untuk mengungkap tumbuhnya kreativitas matematika peserta didik berdasarkan teori modifikasi Bahar \& Maker dimana pertanyaan terbuka yang memiliki karakteristk seperti fluency/kelancaran dan flexibility/keluwesan yang dikerjakan secara elaborasi. Dimensi fluency/kelancaran pada teori graf dapat diketahui ketika peserta didik mengerjakan soal misal tentang isomorfik. Dimensi flexibility/keluwesan pada teori graf dapat diketahui ketika peserta didik mengerjakan soal misal tentang spanning trees/pohon berentang. Dalam artikel ini ditunjukkan juga bagaimana graf teori menggunakan standar dari NCTM yang terkait dengan kreaitvitas matematika.
\end{abstract}

Kata kunci: teori graf, kreativitas matematika, fluency, flexibility 


\section{INRODUCTION}

The role of creativity is very important in every line in the world, especially for working and learning. Creativity ability needs to be applied because it is one of the recommended world of work (Career Center Maine Department of Labor, 2004). Early accounts of mathematical creativity (Hadamard, 1945; Poincaré, 1948) influenced by Gestalt psychology describe the creative process as that of preparation-incubation-illumination and verification (Wallas, 1926) as cited in (Harpen, 2012).

Based on Silver (1997), Mann (2005), dan Bahar \& Maker (2011), that mathematical creativity is a basic ability that students must have in learning mathematics. Graph theory is mathematics branch. It is interesting subject manner. Our claim is that this subject can serve as a tool for growing mathematical creativity. Mathematical creativity of students also needs to be grown through the provision of opend ended problems that contain components of fluency and flexibility.

The open ended questions of graph theory that are used as a disclosure in growing the mathematical creativity of students based on Bahar \& Maker's theory modifications are open ended questions that have characteristics such as fluency and flexibility and have been done in detail/elaboration.

\section{METHODOLOGY}

The method used in this study is Systematic Literature Review (SLR). This method is considered right to produce a synthesis or various fusion reliable academic literature and accurate (Chlakiadaki, 2018). Data collection is done with using google sholar, scopus, ERIC in the forms of article journals, books, reports and article seminar proceedings. All data that obtained is analyzed for presend in a review of this article thorough and structured.

\section{DISCUSSION}

Some experts define creativity from various perspectives, Dogan (2011:16) states that creativity is a skill to find and discover new or original thoughts, or to produce new product that are flexible and original. One of the main indicators of creativity is new results in creativity are solutions that have not been taught by educators or are not found in existing books.

Including Nadjafikah \& Yaftia (2013), creativity is the result of one's ability to produce new ideas. New ideas are related to ideas that have never existed. New ideas generated by someone else can also come from the result of the construction of several ideas that already exist so as to produce ideas that are more complex than before. Grishober (2004) defines creativity as a result of the process of constructing matery that consist of many ascpects are fluency, flexibility and novelty. Then McGragor (2007) that creativity the result of thinking to the aquisiton of new ideas in solving problems that show eloquence, flexibility and and originality in thinking. According to Martin (2009), creativity is the result of a person's ability to be flexible and original to produce new ways of problem solving.

Based on some experts opinion, mathematical creativity is constructing process of personal in studying mathematics that consist of fluency, flexibility, novelty, originality, and elaboration. In this paper, writer discuss about mathematical creativity on graph theory. Based on studied about graph theory, writer describe about some topics on graph theory that can imply in the mathematical learning that it can grow mathematical creativity.

Bahar \& Maker's (2011), suggested that to grow students' mathematical creativity, it was necessary to give open ended problems that were fluency, flexibility, elaboration and were raised simultaneously as indicator bases. Then, students can be drill to do some open ended problems that contain fluency and flexibility components. 
Fluency is the one of some components on mathematical creativity. Fluency is the component that describe about one algorithm on a topic has some solving problem solutions Fluency on graph theory can be known when students do task/exercises such as isomorphic graph. Let discuss about isomorphic on graph theory.

Isomorphism : $G_{1}=\left(V_{1}, E_{1}\right)$ and $G_{2}=\left(V_{2}\right.$, $\left.E_{2}\right)$ are isomorphic if there exists a one-to-one and onto mapping $f$ such that $(i, j) \in E_{1}$ if $(f(i), f(j))$ $\in E_{2}$

$G_{7}$
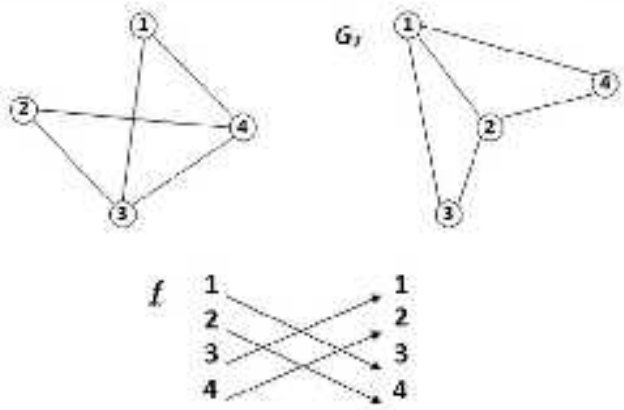

Reliabel $G_{1}$ according to $f$ :
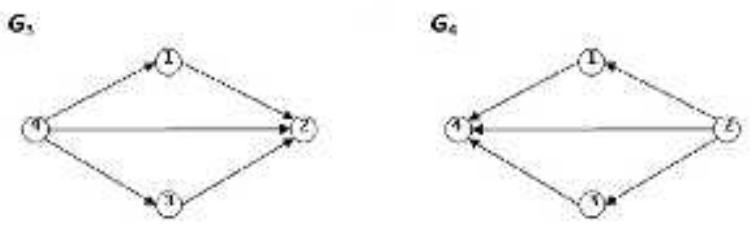

$G_{3}$ and $G_{4}$ are isomorphic.

Flexibility is the one of some components on mathematical creativity. Flexibility is the component that describe about many algorithm to solve problem, and has one solution. Flexibility on theory graph can be known when students do task/exercises such as spanning tree. Let discuss about spanning tree on graph theory. BFS and DFS can define spanning trees, named breadth-first spanning trees and depth-first spanning tress, respectively.

\section{Breadth First Search (BFS)}

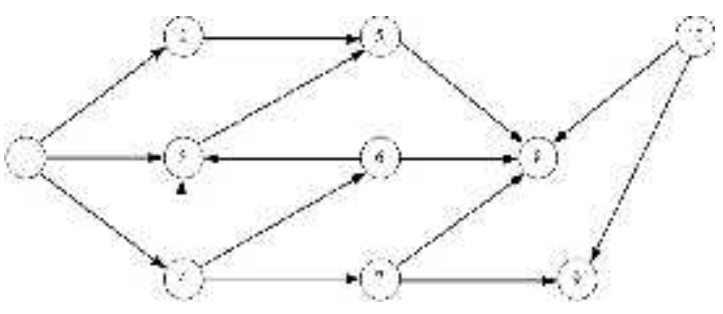

Start at vertex 1 .

$\{1\} \Rightarrow\{2,3,4\} \Rightarrow\{5,6,7\} \Rightarrow\{8,9\}$

Vertex 10 is not reachable from vertex 1 .
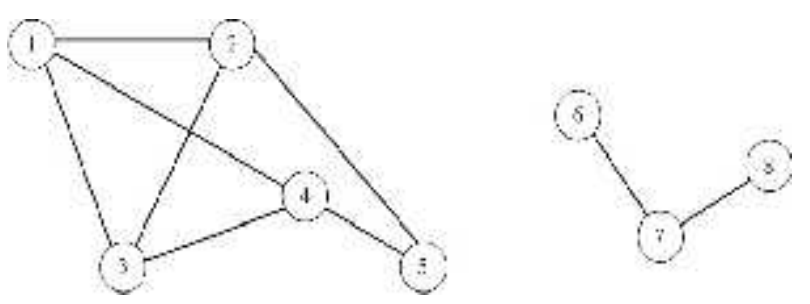

Start at vertex 1 .

$\{1\} \Rightarrow\{2,3,4\} \Rightarrow\{5\}$

Vertices $6,7,8$ are not reachable from vertex 1 . BFS can be used to determine the connected components of an undirected graph.
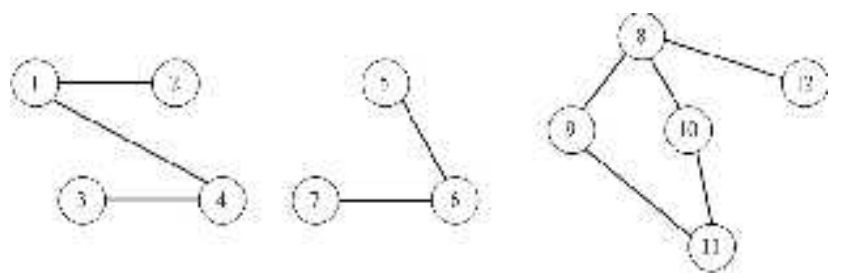

$V=\{1,2,3, \ldots, 12\}$

Step 1. Perform BFS starting at an arbitrary vertex (assume vertex 5).

$\{5,6,7\}$ is reachable from vertex 5 . $\{5,6,7\}$ is a connected component.

Step 2. Repeat Step 1 for an arbitrary vertex (assume vertex 1) from the 
remaining vertices. $\{1,2,3,4\}$ is a connected component.

Step 3. Repeat Step 1 for an arbitrary vertex from the remaining vertices $\{8,9,10$, $11,12\}$ is a connected component.

\section{Depth First Search (DFS)}

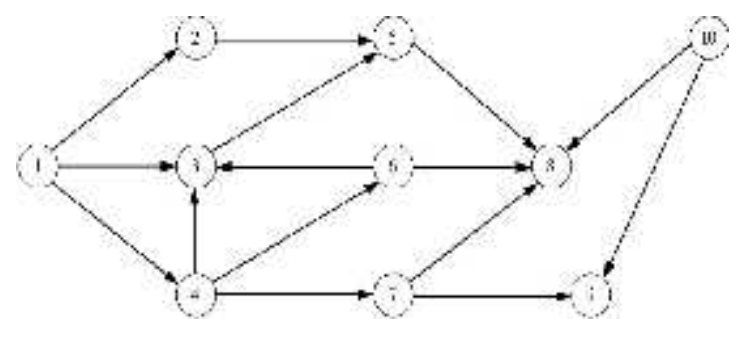

Start at vertex 1 .

$1 \rightarrow 4 \rightarrow 7 \rightarrow 9 \rightarrow 8 \rightarrow 6 \rightarrow 3 \rightarrow 5 \rightarrow 2$
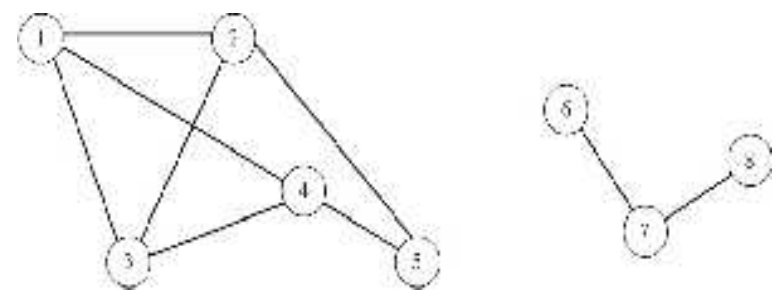

Start at vertex 1 .

$1 \rightarrow 2 \rightarrow 5 \rightarrow 4 \rightarrow 3$

DFS can be also used to determine the connected components of an undirected graph.

\section{Spanning Trees}

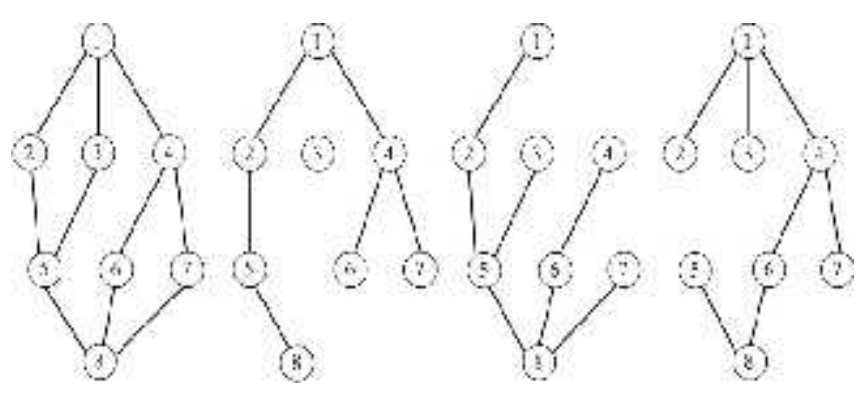

Let $\mathrm{G}=(\mathrm{V}, \mathrm{E})$ be an undirected graph. A subgraph $\mathrm{G} 1=(\mathrm{V} 1, \mathrm{E} 1)$ of $\mathrm{G}$ is a spanning tree of $\mathrm{G}$ if $\mathrm{V} 1=\mathrm{V}$ and $\mathrm{G} 1$ is a tree. BFS and DFS can define spanning trees, named breadth-first spanning trees and depth-first spanning trees, respectively.

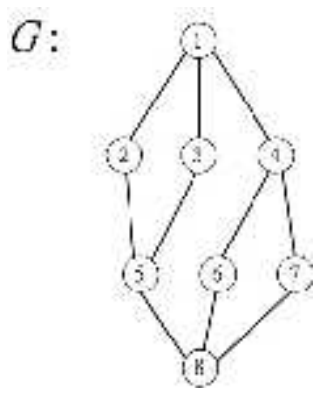

On one hand, based on Asghari (2012) the progress of Discrete-Math and Graph and its application in various sciences such as 'Chemistry, electrical fields, research in operations, computer planning, encoding and social sciences, and the other hand, the declared aims of Math-education by NCTM shows that it is necessary to include the graph theory.

\section{CONCLUSIONS}

The open ended questions of Theory Graph that are used as a disclosure in growing the mathematical creativity of students based on Bahar \& Maker's theory modifications are open ended questions that have characteristics such as fluency and flexibility and have been done in detail/elaboration. Fluency on theory graph can be known when students do task/exercises such as isomorphic graph, dual graph, and the other sub content on graph theory problem that can discuss by other writer/researcher on the next paper. Flexibility on theory graph can be known when students do task/exercises, example about colouring graph using many algotihms such as Welch Powell Algorithm, etc.; and shortest path using Djikstra Algorithm, Chinese Postman Problem 
Algorithm, and the other sub content on graph theory problem that can discuss by other writer/researcher on the next paper. In addition the selection of a learning models depends on the objectives to be achieved by the teacher needs to be discussed next to bring up mathematical creativity.

\section{ACKNOWLEDGMENT}

This article is a part of dissertation work of the first author.

\section{BIODATA}

Puput Suriyah teaches student teachers of Mathematics at the Department of Mathematics Education of IKIP PGRI Bojonegoro, East Java. She is also currently doing a $\mathrm{PhD}$ in Mathematics Education at Universitas Negeri Semarang based in Central Java, Indonesia. She hold an MA in Mathematics Education from Universitas Sebelas Maret Surakarta based in Central Java, Indonesia. Her research interest lie in the teaching of mathematics discreate \& graph theory, bilingual learning, cooperative learning, discovery learning, and mathematical creativity

\section{REFERENCES}

Asghari, N., Shahvarani, A., Haghighi, A.R. 2012. Graph Theory as a Tool for Teaching Mathematical Process. International Journal For CrossDisciplinary Subjects in Education, 3(2), 731-734.

Bahar, A. Kadir. \& Maker, C. June. 2011. Exploring the Relationship between Mathematical Creativity and Mathematical Achievement. AsiaPacific Journal of Gifted and Talented Education, 3(1), 33 - 48.

Career Center Maine Departmeny of Labor. 2004. Today's Work Competence in Maine. Retrieved from http://www.maine.gov/labor/lmis/pdf/Es sential WorkCompetencies.pdf.
Chalkiadaki, A. (2018). A Systematic Literature Review of 21st Century Skills and Competencies in Primary Education. International Journal of Instruction, 11(3), 1-16. Cilliers, E. J. (2017).

Dogan, N. 2011. Creative thinking and creativity. In New Trends in Education (Ed.Ozcan Demirel). Ankara: Pegem Akademi Publication.

Grieshober, W. E. 2004. Continuing a Dictionary of Creativity Terms \& Definition. New York: International Center for Studies in Creativity State University of New York College at Buffalo. Retrieved from http://www.buffalostate.edu/orgs/cbir/R eadingRoom/theses/Grieswep.pdf.I

Hadamard, J. (1945). Mathematician's mind: The psychology of invention in the mathematical field. Princeton, NJ: Princeton University Press.

Harpen, X.Y.V., \& Sriraman, B. 2012. Creativity and mathematical problem posing: an analysis of high school students' mathematical problem posing in China and the USA. Educ Stud Math 82:201-221 DOI 10.1007/s10649-0129419-5, published online: 11 July 2012, Springer Science+Business Media B.V. 2012, page 201-221

Mann, Eric L. 2005. Mathematical Creativity and School Mathematics : Indicators of Mathematical Creativity in the Middle School Students. Diakses dari https://opencommons.uconn.edu/disserta tions/AAI3205573/

Martin. 2009. Convergent and Divergent Thinking. Retrieved from http://www.eruptingmind.com/converge nt-divergent-creative-thinking/[20 Maret 2009]

McGregor, D. 2007. Developing Thinking Developing Learning. Poland: Open University Press. 
Nadjafikhah, M., \& Yaftian, N. 2013 The Frontage of Creativity and Mathematical Creativity. Procedia - Social and Behavioral Sciences, 90(InCULT 2012), 344-350.

https://doi.org/10.1016/j.sbspro.2013.07. 101

Poincaré, H. (1948). Science and method. New York: Dover Books.

Silver, E. 1997. Fostering Creativity through Instruction Rich in Mathematical Problem Solving and Problem Possing. Diakses dari https://www.emis.de/journals/ZDM/zdm 973a3.pdf

Wallas, G. (1926). The art of thought. Harmondsworth, UK: Penguin Books Ltd. 